\title{
Mick J. Perez-Cruet, Richard G. Fessler, Michael Y. Wang: An anatomic approach to minimally invasive Spine surgery
}

\section{Second edition, Thieme Verlag New York, Stuttgart, Delhi, Rio de Janeiro, 2019, 580 pp.; 439 figs.; Hardcover, EUR (D) 259,99 EUR (A) 267,30, ISBN 978-1-62623-643-1}

\author{
Alain G. Graftiaux ${ }^{1}$. Pierre H. Kehr ${ }^{1}$
}

Received: 10 August 2019 / Accepted: 14 September 2019 / Published online: 30 September 2019

(c) Springer-Verlag France SAS, part of Springer Nature 2019

Minimally invasive surgery of the spine has its followers, but requires a good preparation for the one who plans to do it. The purpose of this book is to provide the necessary elements.

The first and second parts concern the anatomical and physio-pathological bases of lumbar pain as well as the organization of the operating room as well as the organization of an outpatient surgery center, the organizational implications and the patient's involvement.

The third part deals with operative techniques, monitoring, navigation, stereotaxis and diagnostic and therapeutic injections.

The fourth part presents the surgical techniques according to cervical, thoracic or lumbar localization.

The fifth part deals with tumor surgery.

The sixth part presents an analysis of the results and complications.
The last part opens with the future with stem cells.

It is therefore a book and a very complete e book that will interest both new and experienced surgeons as well as orthopedic surgeons and neurosurgeons or more widely all the surgeons in the column who want to know more or initiate mini-invasive surgery of the spine.

\section{Compliance with ethical standards}

Conflict of interest The authors declare that they have no conflict of interest.

Publisher's Note Springer Nature remains neutral with regard to jurisdictional claims in published maps and institutional affiliations.
Pierre H. Kehr

pierre.kehr@gmail.com

1 Strasbourg, France 